\title{
IMPACT OF LAND USE CHANGES THE CATCHMENT ON THE QUALITY AND QUANTTTY OF WATER IN THE RAJANGANA RESERVOIR
}

\author{
N S Abeysinghe', D M S H K Ranasinghe', and R Attygalle 2 \\ 'Department of Forestry \& Environmental Science, University of Sri Jayewardenepura \\ 2Mahaweli Authority of Sri Lanka
}

The condition of the watershed plays an important role in the quality and quantity of the water of reservoirs. Among the factors, which affect the health of a watershed, are climate, geology and land use management. Rajangana watershed drains water to the Rajangana reservoir, which irrigates about 5520 ha in the dry zone.

In the present study, total monthly inflows to the reservoir were calculated through a water balance study and water inflows from the catchments were obtained through a sensitivity analysis using past records. Land use changes were studied by using existing land use maps (I: 50,000) using GIS software. Some water quality parameters in the reservoir waters were analysed. These parameters were compared with the ones taken during the past 10 years from past records of the MASL in order to identify any trends with the changes of rainfall, temperature, land use etc.

The results showed that the annual total water inflow and also the inflow during the dry season decreased with time. These trends correlated with the increase in built up areas, reduction of forest cover. Further, there was a marked increase of the $\mathrm{pH}$ and alkalinity in the waters with time.

\footnotetext{
Proceedings of the Ninth Annual Forestry and Environment Symposium 2003 of the Department of Forestry and Environmental Science. University of Sri Jayewardenepura. Sri Lanka
} 